\title{
Professional Training of the Economic Sector Specialists at Higher Education Institutions of the Republic of Poland and Ukraine: Criteria of Comparison
}

\author{
Alla Zagorodnya ${ }^{1}$, Natalia Dichek ${ }^{1}$, Nikolai Chobitko ${ }^{2}$, Mikhail Voznyk $^{1}$, Liubov Honchar $^{3}$ \& Mariana Petrova ${ }^{4}$ \\ ${ }^{1}$ Institute of Pedagogy of the National Academy of Sciences of Ukraine, Kiev, Ukraine \\ ${ }^{2}$ Kamianets-Podilskyi National Ivan Ohiienko University, Kamianets-Podilskyi, Ukraine \\ ${ }^{3}$ Donbass State Pedagogical University, Slavyansk, Ukraine \\ ${ }^{4}$ St.Cyril and St.Methodius University of Veliko Tarnovo, Bulgaria \\ Correspondence: Mariana Petrova, St.Cyril and St.Methodius University of Veliko Tarnovo, Bulgaria.
}

Received: February 10, 2020

doi:10.5430/ijhe.v9n3p139
Accepted: March 11, 2020

Online Published: March 12, 2020

URL: https://doi.org/10.5430/ijhe.v9n3p139

\begin{abstract}
The article deals with the comparative analysis of the issues of the economic sector specialists' professional training at higher education institutions of the Republic of Poland and Ukraine. The essence of the concept of "economic sector specialists' professional training" has been revealed. The component structure of the economic sector specialists' professional training has been determined. The criteria of comparison of the economic sector specialists' professional training at higher education institutions of the Republic of Poland and Ukraine have been highlighted, namely: institutional-network; organizational-step; substantive-procedural. The results of the comparative analysis have been described.
\end{abstract}

Keywords: university, economic education, research concept, educational environment, vocational training, comparative pedagogy

\section{Introduction}

In the conditions of the rapid development of the economy, the fast pace of globalization and innovative changes, each society seeks to ensure its competitiveness in the global market of intellectual resources. Therefore, the reform of education in order to ensure the quality of educational services in modern conditions of transient Euro-integration processes is becoming a priority of the educational policy of most countries in the world. In the documents of the international organizations, in particular of the European Union (EU), the United Nations Educational, Scientific and Cultural Organization (UNESCO), the Council of Europe (CE), the World Bank (WB), the International Labour Organization (ILO), the Organization for Economic Cooperation and development (OECD which influence the formation of the modern ideas about civilizational progress, human capital is recognized as a crucial factor in the economic growth of the countries, increasing their competitiveness in the world labour market. That is why the international community emphasizes the key role of education in enhancing the economic and social well-being of each country.

One of the important problems of the Ukrainian labour market is the imbalance in the professional training of specialists in the economic sector and their demand in the labour market. Today, the employer is de facto removed from the process of formation and control of such a public institution as the "state order", he does not participate in the formation of the education content. There are a lot of discussions around the development of economic education in Ukraine and the professional training of specialists in the economic sector, in particular on the quantity and quality of training of future economists, the set of key competencies of graduates, the humanization of economic training, and the like. Under such conditions, increasing the efficiency of professional training of specialists in the economic sector is one of the priority tasks of the system of higher economic education.

In the EU countries, a set of measures has been implemented to ensure the effectiveness of professional training of specialists in the economic sector in an integrated international educational space. This applies, first of all, to improving the regulatory framework for the training of specialists in the economic sector; strengthening the integration of professional training of specialists in the economic sector with science and production potential; 
changes in the tasks of training specialists in the economic sector; updating curricula; introduction of distance learning; increasing the level of individualization of professional training of specialists in the economic sector using modern information technologies.

That is why for the effective modernization of higher economic education in Ukraine, the solution to the problem of training competitive specialists in the economic sector, it is relevant to study the experience of the countries of the European Union and Poland in particular, primarily because of the similarity of educational changes that are taking place in Ukraine today and have already taken place in Poland. A significant reason is the fact that Poland has come a long way in socio-economic development, has become a member of the European Union and has joined the European standards for specialists' training.

That is why problem of specialists' professional training in the economic sector at higher education institutions is complex. The concerted efforts of representatives of various training courses and disciplines are necessary in order to form a systemic idea of the phenomenon of efficiency, conditions, criteria, factors of its increasing and methods of measurement.

The purpose of the article is to highlight and substantiate the criteria of comparison of specialists' professional training in the economic sector at higher education institutions of the Republic of Poland and Ukraine.

The objective of the study is to determine the general and various characteristics in specialists' professional training in the economic sector at higher education institutions of the Republic of Poland and Ukraine, namely: a network of institutions of higher economic education of the Republic of Poland and Ukraine; models of specialists' professional training in the economic sector at higher education institutions of the Republic of Poland and Ukraine; the contents, forms and methods of specialists' professional training in the economic sector at higher education institutions of the Republic of Poland and Ukraine.

\section{Analysis of the Research and Publications}

The theoretical basis of the study consists of the conclusions of theories and concepts regarding specialists' professional training in the economic sector at higher education institutions of the Republic of Poland and Ukraine (K. Berkit, M. Vachevsky, N. Volkova, T. Grygorchuk, M. Kolyada, A. Mykhailov, I. Moroz, T. Poyasok, G. Blazheyovsky, S. Kwiatkowski, S. Kaczor, S. Kmec, T. Novatskiy, W. Okoń, F. Schlosek, G. Tadusewych, Z. Wiatrowski and others).

Domestic and foreign researchers note that in an innovative economy, the efficiency and effectiveness of the interaction of economic actor's increases significantly from the organization of integration processes as a condition for the effective functioning of the management system of complex social and economic systems (Duginets\&Petrova, 2020; Gryshova et al, 2019; Naama, 2001; Popova, 2016; Petrova et al, 2020; Petrova et al, 2019; Nenkov ae al, 2017; Mussapirov et al, 2019; Mikhailov at al, 2018; Linde\&Petrova, 2019; Uteubayev et al, 2019; Lazarova et al, 2015; Jarmusevica et al, 2019).

Among the recognized scientific and pedagogical community of Ukraine and the Republic of Poland, conceptual trends in higher economic education -and in particular, in specialists' professional training in the economic sector at higher education institutions of the Republic of Poland and Ukraine - have become the subject of numerous scientific and pedagogical studies, and here can be mentioned several determining ones. The concept of "profesjonalne szkolenie specjalistów w dziedzinie gospodarki" (specialists' professional training in the economic sector) is considered as a specially organized process for the acquisition of economic knowledge, skills and abilities by future specialists in the process of studying the system of professionally directed disciplines of the economic cycle and the formation of professionally significant qualities of a personality necessary for future professional activities (Gerlach, 2017; Maison, 2015).

Based on the analysis of the scientific literature, it should be noted that in Ukraine the professional training of specialists in the economic profile is studied as the following: the area of formation and development of the economic education system as a whole; a compulsory component in the system of professionally oriented education in various types of higher education institutions; a necessary structural component of the professional skill of an economic profile specialist; a component of a modern specialist's general and professional culture. (Zagorodnia 2016, p. 291).

As M. Petrova rightly notes, the formation of a future specialist's competencies should stipulate such an educational environment which is able to provide a combination of applied and fundamental training of future specialists; mastery of professional activity; professional training and education; the ability to see the problem independently and find ways to solve it (Petrova et al, 2018). 


\section{Methods}

The theoretical and methodological basis of the study is a systematic approach to the study of the fundamental principles of specialists' professional training in the economic sector at higher education institutions of the Republic of Poland and Ukraine. To solve the tasks, the following general scientific methods were used:

1)the analysis and synthesis method (with the aim of revealing the conceptual and categorical apparatus of the research and the scientific justification of pedagogical conditions for specialists' professional training in the economic sector at higher education institutions of the Republic of Poland and Ukraine);

2)scientific abstraction, induction and deduction (when summarizing the domestic and Polish experience of specialists' professional training in the economic sector at higher education institutions of the Republic of Poland and Ukraine);

3)abstract-logical (for the theoretical generalization of the results of research and the formulation of conclusions); special methods:

mathematical and statistical processing of the research results - for the analysis of the obtained data, ranking, scaling, registration, systematization and differentiation, grouping, graphic expression of the data.

Using a set of methods allowed obtaining objective information about the conditions for specialists' professional training in the economic sector at higher education institutions of the Republic of Poland and Ukraine. The results of the study are presented using charts, tables and graphical images.

\section{Results and Discussions}

The professional training of modern economists requires their understanding of the laws governing the formation and development of reproductive processes at the macro and micro levels, in conjunction with the development of political, cultural and other social processes. Economic education covers four blocks of disciplines that form the modern worldview and determine the need for constant updating of socio-economic knowledge and skills: general education, fundamental, innovative and practical, and a block of special training disciplines. The disciplines included in these blocks provide a comprehensive multi-aspect study of the laws of the economic sphere of society. The formation of the economic knowledge is realized through a combination of cognitive, theoretical and practical components of training. Moreover, the cognitive components do not only create a system of financial, technological, technical, economic and legal knowledge, but also determine young people's internal culture, shape their willingness to consciously harmonize the relationship "human - society - nature - economy".

It is also advisable to highlight the specialists' professional training functions in the economic sector at technical universities that provide students with the acquisition of professionally-oriented economic knowledge and skills, such as:

1) general theoretical - aimed at the formation of fundamental economic concepts and patterns;

2) practical-applied - contributes to the formation of professionally-oriented economic knowledge, skills;

3) organizational and managerial - aimed at students' understanding of the essence of the managerial and marketing-selling activities of a future specialist;

4) personality-adaptation - provides a future specialist's adaptation to the modern labour market.

Among the areas of professional training of specialists in economic profile in Poland and Ukraine are: "Economics"; "Finance and accounting"; "Spatial economy"; "Econometrics"; "Finance and accounting"; "Management and administration"; "Tourism and business recreation"; "International relationships"; "Information Management Marketing"; "Management"; "Finance and insurance"; "Finance and goods"; "Logistics and financial market"; "Business".

A comparative analysis of specialists' professional training in the economic sector at higher education institutions of the Republic of Poland and Ukraine was carried out according to the following criteria: institutional-network; organizational-step; substantive-procedural. The indicators revealing the contents of each criterion were also substantiated.

The institutional-network criterion contains such indicators as: a network of higher economic educational institutions of the Republic of Poland and Ukraine; models of professional training of specialists in the economic sector. The organizational-step criterion is determined by such indicators as the degree of future specialists' professional training in the economic sector; types of specialists' qualifications in the economic sector. A substantive-procedural, related to the contents of an economic specialist's professional training and namely the forms and methods of specialists' 
training in the economic sector.

Criteria of effectiveness (Eng. Criteria of effectiveness, Pol. Kryterium efektywnosci) are measurements or benchmarks used to measure achievement of performance standards. Effectiveness criteria, as qualitative indicators, characteristics or standard values for evaluating a student's effectiveness, show how students meet the expectations of the things they need to know and be able to do, which is expressed in levels or grades (Vasyliuk, 2013; p. 86).

Based on an analysis of Polish scientific research, S. Sysoieva defines the following performance criteria suggested by her for assessing the professional training system functioning (Sysoieva, 2009, p. 219):

1) operational, associated with the organization and course of the main processes of activity and expressing the objective laws of their development, as well as the result of achieving goals or fulfilling certain needs;

2) economic, associated with the magnitude (weight) of positive effects (useful) and negative (imprints) that express the usefulness of the system relative to the main activity (creation, providing services, etc.) - they are called simulators and destimulants;

3) information criteria related to the organization of the system and the course of information processes expressing the influence of these processes on the behaviour of the system;

4) technical criteria that are related to the readiness of system elements, especially technical means, expressing the influence of a technique on the behaviour of the system;

5) operational criteria related to the functioning of the means of activity expressing the influence of the activity functioning means on the system ability to act effectively within certain time limits.

Thus, in our study, the comparative criteria for specialists' professional training in the economic sector at higher education institutions of the Republic of Poland and Ukraine are a measure of the signs that determine the real modern trends in the professional training of future economists in Poland and Ukraine. Therefore, it is necessary to pay attention to the significance of the evolution processes of Western education systems which take place in foreign theory and practice of education - namely specialists' professional training in the economic sector at higher education institutions.

\section{Results Analysis}

According to the information of the Ministry of Science and Higher Education of Poland, at the end of 2018, about 450 higher educational institutions were functioning in the country, including 138 state educational institutions and 310 private ones. But in Ukraine there are 64 specialized economic universities, professional training of specialists in the economic sector is also carried out by other (218) institutions of higher education at the 6-7th level of ISCED. In 2018/2019, the number of institutions of higher economic education in Ukraine amounted to 190, among them 63.0\% are private property institutions and $37.0 \%$ are state property ones.

The models of specialists' professional training in the economic sector at higher education institutions of the Republic of Poland are: socially-oriented (takes into account the requests of territorial communities and the local socio-economic environment) individualized-liberal (the emphasis is made on personal requests of a student as a subject of professional formation in the learning process); integrative (takes into account the needs of the corporate environment and socio-economic development strategies).

The most common models of specialists' professional training in the economic sector in Ukraine are the following: regulatory-step-legal documents in the field of education determine the educational levels of specialists training; and an integrative model which takes into account the requirements and strategy of the educational environment at the level of a higher education institution (integration of colleges and lyceums as structural units of higher education institution; integration with foreign higher education institutions in the training of specialists for obtaining two diplomas).

In accordance with the organizational-step criterion, it should be noted that the higher education systems of Ukraine and Poland provides three-stage training for specialists in the following educational levels, such as: Bachelor (BA, licencjat) Bachelor (BSc, inzynier; Master (MA, MSc, magister), Doctor of Sciences (PhD, doktor). The duration of specialists' training in the economic profile is approximately the same: bachelor's degree program (3 - 3.5 - 4 years), master's degree program (1.5 - 2 years).

Among the distinguishing features of the organization of specialists' training in the economic sector in Ukraine we should note the following: narrow professional specialization; teaching foreign languages; humanization of economic education. 
Due to the data obtained according to the substantive-procedural comparative criterion, it has been proved that the structure of the contents of economic education at higher education institutions of the Republic of Poland is determined by the following main blocks: educational, special, psychological and pedagogical, sociocultural, scientific and professional, practice-oriented. The contents of specialists' professional training in the economic sector at higher education institutions of Ukraine are determined by such blocks as: normative, selective, psychological and pedagogical, competence (general professional; special professional), resultative.

Specialists' professional training in the economic sector at higher education institutions of Ukraine is carried out through such forms and methods: traditional lectures, seminars, practical and laboratory classes, educational research, independent written work, interactive game forms and methods: interactive lecture, computer seminars, video conferencing, online training, case training, project method, role-playing and business games, professional and simulation modelling, training technologies, which involve mastering a stable foundation of theoretical knowledge, building readiness for innovation, developing the ability of creative thinking and creative abilities that contribute to solving critical production problems. A distinctive feature of the Polish higher education institutions in training specialists in the economic sector is the use of the following forms and methods: pro-seminars, surfing the Internet, "mass open online course (MVOK)", a method of staging authentic events (facts) in the aspect of studying the development of the economy, fascination technology, study tours, company visits, and summer schools.

\section{Conclusions}

According to the results of the study, the following conclusions can be drawn. The network of economic higher educational institutions of Ukraine includes universities, higher schools, academies which offer a system of compulsory courses, as well as business schools, special academic programs, business education centres. The network of the economic higher education institutions of the Republic of Poland covers universities, higher schools and academies. The construction of the educational process at institutions of higher economic education of the Republic of Poland and Ukraine is based on similar socio-humanitarian and general educational didactic principles, using the traditional type of teaching with a predominance of explanatory, illustrative and problem-developing teaching, while the dominant types of training are lectures and seminars.

It has been proved that at higher educational institutions of the Republic of Poland individual-group forms of educational interaction prevail using interactive teaching methods and innovative educational process organization technologies (video lectures, practical training sessions, developed distance learning network, cluster method, etc.) At the same time, verbal-visual-practical teaching methods prevail at higher education institutions of Ukraine, distance education system is mainly practiced as an auxiliary, for the purpose of students' self-education, and insufficient material, technical and information-computer equipment limits the ability to fully use digital and Internet technologies in the educational process of higher educational institutions.

However, the undertaken study does not exhaust the fullness of the problem of specialists' professional training in the economic sector at higher education institutions of the Republic of Poland and Ukraine. Further research requires such important aspects of the problem as the analysis of the imbalance of supply and demand for specialists in the economic sector in the modern labour market.

\section{References}

Duginets, G., Petrova, M. (2020). The essence of hybrid wars in the XXI century. Professional competencies and educational innovations in the knowledge economy: collective monograph / Ed: Lyubomira Popova, Mariana Petrova. Veliko Tarnovo, Bulgaria: Publishing House ACCESS PRESS, 2020. -552 p. ISBN 978-619-91511-0-5, 174-189, http://access-bg.org/ebooks

Gerlach R. (2017). Edukacja zawodowa zorientowana na rynek pracy [in Polish]. Uniwersytet zielonogórski .Polskie towarzystwo profesjologiczne. Problemy Profesjologii, 1, 23-33.

Gryshova, I.; Petrova, M.; Tepavicharova, M.; Diachenko, A.; Gutsul, T. (2019). A model for selection of a management team to ensure the sustainability and development of the business organizations, Entrepreneurship and Sustainability Issues, 7(1), 690-703. https://doi.org/10.9770/jesi.2019.7.1(49)

Jarmusevica, V.; Ilisko, D.; Badjanova, J.; Jukss, V.; Petrova, M. (2019). Educating citizens for implementing the strategy of corporate social responsibility for sustainable regional development: the case study. Proceedings of EDULEARN19 Conference 1st-3rd July 2019, Palma, Mallorca, Spain, ISBN 978-84-09-12031-4, 10449-10454

Lazarova, T., Zhelyazkova, V., Vazov, R. (2015). Innovation leadership as a key concept in entrepreneurship. The 
8th International Conference for Entrepreneurship, Innovation and Regional Development. 18th and 19th June 2015 Conference proceedings, University of Sheffield

Linde I., Petrova M. (2018). The challenges of Formalization and Modeling of Higher Education Institutions in the 21st century. CBU International Conference Proceedings 2018: Innovations in Science and Education. 303-308. https://doi.org/10.12955/cbup.v6.1173

Maison D. (2015). Przeglad programow z zakresu edukacji ekonomicznej polakow [in Polish]. Ruch pedagogiczny, 1 , $125-136$.

Mikhailov, V., Karasev, V., Mikhailov, G. (2018). The Study of the Main Indicators of the Local Environmental and Economic System "Industrial Enterprise-Environment". E3S Web Conf. 41, 2018. III ${ }^{\text {rd }}$ International Innovative Mining Symposium. https://doi.org/10.1051/e3sconf/20184102015

Mussapirov, K., Djalkibaev, J., Kurenkeyeva, G., Kadirbergenova, A., Petrova, M., Zhakypbek, L. (2019). Business scaling through outsourcing and networking: selected case studieS. Entrepreneurship and Sustainability Issues, 7(2), 1480-1495. https://doi.org/10.9770/jesi.2019.7.2(48)

Naama, K. (2001). "International Movement of Foreign Direct Investments," Economic Thought journal, Bulgarian Academy of Sciences - Economic Research Institute, 5, 81-92.

Nenkov N., Dyachenko Y., Petrova M., Bondarenko G. \& V. Pustovit. (2017). Intelligent and Cognitive Technologies in Education of International Economic Relations Students and Human Resource Development in Enterprises: Methodology in Language. European Journal of Sustainable Development. Publisher: European Center of Sustainable Development. Rome, Italy, Vol 6, No.4, 2017, 353-360. https://doi.org/10.14207/ejsd.2017.v6n4p353

Petrova M., Buzko I, Dyachenko Yu. (2018). Cognitive, Intelligence Technologies and Economical Foundations of Teaching of International Economical Relations and Tourism. 17th International Scientific Conference ERDev, 23.-25.05.2018. Jelgava, latvia, 1102-1106. https://doi.org/10.22616/ERDev2018.17.N170

Petrova, M., Tepavicharova, M., Dikova, L. (2019). Factors for development of the educational and professional qualification profile of the human resources in the machine building sector in Bulgaria. ISPCIME-2019. MATEC Web of Conferences, vol.297 (06015). https://doi.org/10.1051/matecconf/201929706001

Petrova, M., Koval, V.,Tepavicharova, M., Zerkal, A., Radchenko, A., Bondarchuk, N. (2020). The interaction between the human resources motivation and the commitment to the organizations. Journal of Security and Sustainability Issues, 9(3). http://doi.org/10.9770/jssi.2020.9.3(15)

Popova L. Possibilities for coping with professional stress in teachers. Economics \& Education. (2016). Riga, Latvia, № 1 (1). C. 33-35. https://ee.isma.lv/issues/E_E_0101/09_E_E_0101_Popova.pdf

Sysoieva S.O. (2009). Continuing pedagogical education: modern paradigms and technologies for their implementation [in Ukrainian]. Materials left. ambush. Scientific School on Creativity and Technology in Continuing Professional Education (Khmelnitsky, May 14-16, 2009): scientific publication; in a row. S.O.Sysoieva. Khmelnytskyi, 339.

Uteubayev, T., Petrova M.M., Lyubenova, I. (2018). Training of qualified specialists in the process of their education at the university: the role of the public-private partnership. $\mathrm{CBU}$ International Conference Proceedings 2018: Innovations in Science and Education. pp.491-495. https://doi.org/10.12955/cbup.v6.1203

Vasyliuk A.V. (2013). Pedagogical Dictionary-Lexicon (Ukrainian-English-Polish).(2nd ed.) [in Ukrainian]. Nizhyn: Publisher of PP Lysenko, 224.

Zagorodnia A. A. (2016). Professional training of specialists for the economic branch in higher school of Ukraine. Trends in der Entwicklung der nationalen und internationalenWissenschaft: Sammelwerk der wissenschaftlichenartikel. Verlag SWG imex GmbH, Nürnberg, Deutschland, 290-293. 